\title{
MAINTENANCE OF PREGNANCY IN THE HAMSTER BY A SINGLE CORPUS LUTEUM FROM DAY 12
}

\author{
HARRY M. WEITLAUF AND GILBERT S. GREENWALD \\ Departments of Obstetrics and Gynecology and Anatomy, \\ University of Kansas Medical Center, Kansas City, Kansas, U.S.A.
}

\section{(Received 22nd June 1967)}

The amount of luteal tissue essential for the maintenance of pregnancy has been determined for various laboratory species. From early experiments and those cited below, it seems clear that different amounts of luteal tissue are necessary at different stages of pregnancy if gestation is to continue. In the rabbit, blastocysts fail to expand in the absence of luteal tissue (Corner, 1928; Adams, 1965), but one to two corpora lutea are sufficient for endometrial proliferation (Brouha, 1934; Adams, 1965); whereas two to four corpora lutea are necessary to depress myometrial activity enough to prevent expulsion of the unattached blastocysts (Adams, 1965). Bilateral ovariectomy after implantation terminates pregnancy in the rabbit (Csapo, 1956).

Destruction of the corpora lutea of the rat on Days 3 to 7 of pregnancy or pseudopregnancy leads to the resumption of oestrous cycles within 7 days, while ablation of the corpora lutea on Days 11 to 16 of pregnancy induces abortion or embryonic resorption (McKeown \& Zuckerman, 1938). A minimum of two corpora lutea are required to maintain pregnancy in the rat from Day 8 until term (Kelsey \& Meyer, 1950).

Removal of both ovaries of the hamster on Days 9 to 13 of pregnancy induces abortion (Klein, 1938). Progesterone alone is unable to maintain pregnancy in the ovariectomized hamster but the concurrent administration of small doses of oestrogen permits pregnancy to continue normally (Klein, 1938; Grady, unpublished observations). On the other hand, it has been reported that exogenous progesterone is sufficient to induce implantation in ovariectomized hamsters (Orsini \& Psychoyos, 1965; Harper, 1966) and pregnancy can be maintained at least to Day 14 with progesterone alone (Harper, 1966). Progesterone is, therefore, necessary for the continuation of pregnancy in ovariectomized hamsters, while the necessity for oestrogen is still in question.

In the present experiments an electro-cautery needle was used to destroy the corpora lutea of pregnancy in hamsters in an attempt to find the minimal amount of luteal tissue required to maintain pregnancy when follicular tissue was left intact. Only animals which had visible implantation sites at autopsy are included in this report. 
Eighteen hamsters were mated and the day of spermatozoa in the vagina was designated as Day 1 of pregnancy. On Day 12 of pregnancy the animals were anaesthetized with pentobarbital and all visible corpora lutea were destroyed by cautery. Day 12 was selected because follicular development is maximal (Greenwald, 1964) and presumably provides sufficient oestrogen to synergize with progesterone in the maintenance of pregnancy. The females were checked twice daily for vaginal bleeding or newborn young. At the time of abortion or delivery the females were killed and their ovaries removed and fixed for subsequent histologic examination in serial sections. Each animal was classified on the basis of the amount of luteal tissue remaining in both ovaries as determined from serial sections (Table 1).

TABLE 1

\begin{tabular}{|c|c|c|c|c|}
\hline Group & $\begin{array}{l}\text { No. of } \\
\text { corpora lutea } \\
\text { remaining }\end{array}$ & $\begin{array}{l}\text { No. of } \\
\text { animals }\end{array}$ & $\begin{array}{c}\text { No. of } \\
\text { antral follicles } \\
\text { Mean } \pm \text { S.E. }\end{array}$ & $\begin{array}{c}\text { Results: average } \\
\text { no. of full-term } \\
\text { young } \pm S . E .\end{array}$ \\
\hline 1 & $\begin{array}{c}\text { Bilateral ovariectomy } \\
\text { at Day } 12\end{array}$ & 5 & 0 & Aborted Day 14 \\
\hline 2 & $\mathbf{0}$ & 2 & $17 \cdot 5$ & Aborted Day 15 \\
\hline 3 & 1 & 6 & $20 \cdot 8 \pm 2 \cdot 9$ & $\begin{array}{l}\text { Parturition Day 16; } \\
\text { young } 6.7 \pm 1.4\end{array}$ \\
\hline 4 & 2 & 2 & $22 \cdot 0$ & $\begin{array}{l}\text { Parturition Day 16; } \\
\text { young } 9.0\end{array}$ \\
\hline 5 & 3 or more & 3 & $21 \cdot 4 \pm 6 \cdot 6$ & $\begin{array}{l}\text { Parturition Day 16; } \\
\text { young } 8.7 \pm 1.2\end{array}$ \\
\hline
\end{tabular}

The effects of varying amounts of luteal tissue on the course of pregnancy are summarized in Table 1. Bilateral ovariectomy (i.e. total absence of luteal and follicular tissue) led to abortion in 2 days (Group 1). Ablation of all luteal tissue with follicular and interstitial tissue still intact likewise caused abortion (Group 2). On the other hand, the presence of one or more corpora lutea maintained pregnancy and allowed normal delivery (Groups 3, 4 and 5). Some of the animals reported as having one corpus luteum actually had only a portion of a single corpus luteum remaining. Thus, even a small remnant of corpus luteum in conjunction with intact follicular and interstitial tissue, can maintain pregnancy in the hamster from Day 12. It should be noted that there was essentially no difference in the ovarian weights or numbers of antral follicles in Groups 2 to 5 . Follicles were considered as antral stages if any cavitation was found between the granulosa cells; all follicles measured were greater than $277 \mu$ in diameter and most were between 400 and $600 \mu$.

The present results raise the question: How can a small remnant of corpus luteum maintain pregnancy? Possibly the remnant is stimulated to produce more progesterone per mg of tissue than it normally does and is thus able to compensate for the corpora lutea which are removed. Alternatively, the luteal remnant may continue to function at its normal rate and only small amounts of progesterone be necessary to maintain pregnancy when follicular and inter- 
stitial tissue are present. If the latter explanation is correct it would suggest that in normal hamster pregnancy much more progesterone is produced than actually needed.

This is a contribution from the Research Professorship in Human Reproduction. H.M.W. was supported as U.S.P.H.S. post-doctoral Fellow. The research was supported by grants from NIH (HD-00596) and the Ford Foundation.

\section{REFERENCES}

Adams, C. E. (1965) Influence of the number of corpora lutea on endometrial proliferation and embryo development in the rabbit. $\mathcal{F}$. Endocr. 31, xxix.

Brouha, A. (1934) Etude des rapports entre les modifications pre-gravidiques de la muquese uterine et les hormones ovariennes. Archs Biol., Paris, 45, 571.

Corner, G. W. (1928) Physiology of the corpus luteum. Am. F. Physiol. 86, 74.

Csapo, A. (1956) Progesterone block. Am. 7. Anat. 98, 273.

Greenwald, G. S. (1964) Ovarian follicular development in the pregnant hamster. Anat. Rec. 148, 605.

HARPER, M. J. K. (1966) Implantation and embryonic development in the ovariectomized hamster. Acta endocr., Copenh. 52, 465.

KELSEY, R. C. \& MEYER, R. K. (1950) Amount of luteal tissue required for maintenance of pregnancy in the rat. Proc. Soc. exp. Biol. Med. 75, 736.

KLEIN, M. (1938) Relation between the uterus and the ovaries in the pregnant hamster. Proc. $R$. Soc. B, $125,348$.

MaKeown, T. \& Zuckerman, S. (1938) The suppression of oestrus in the rat during pregnancy and lactation. Proc. $R$. Soc. B, 124, 464.

Orsini, M. W. \& Psychoyos, A. (1965) Implantation of blastocysts transferred into progesterone treated virgin hamsters previously ovariectomized. F. Reprod. Fert. 10, 300. 